\title{
Fisheries Governance
}

\begin{abstract}
This chapter examines the role that governance plays in shaping fishing livelihoods. This includes formal government regulation as well as other factors that shape fishing, such as markets, buyer requirements and social norms. Institutional arrangements serve as a key component of fishing livelihoods, by prescribing the conditions under which fishing livelihoods operate. In this chapter we sketch out some of the trends in fisheries governance across parts of the Asia-Pacific, before discussing examples in Australia and Indonesia.
\end{abstract}

Keywords Fisheries governance $\bullet$ Neoliberalism • Resource nationalism - Indonesia • Australia

This chapter turns to an examination of the role that governance plays in shaping fishing livelihoods. While fishing has long been perceived as a classic example of the 'tragedy of the commons' the reality is that most if not all fishing livelihoods are significantly affected by some sort of institutional arrangements (Kooiman et al., 2005; Ostrom, 1990). These institutional arrangements serve as a key component of fishing livelihoods, by prescribing the conditions under which fishing livelihoods operate. This chapter

\footnotetext{
${ }^{1}$ Or more accurately, the tragedy of open access (Bromley \& Cernea, 1989; Ostrom, 1990).
} 
sketches out some of the trends in fisheries governance across parts of the Asia-Pacific, before moving on to discuss examples in Australia and Indonesia.

Adapting a definition from Hall et al. (2011: 16) in relation to land, here we consider governance as the formal and informal rules that govern access and exclusion over fisheries resources. While state-based governance is most commonly thought of when governance is discussed, many other wider sets of social institutions regulate access to and exclusion from fisheries resources (Bromley, 1992; Kooiman et al., 2005; Ostrom, 1990). In addition to government, civil society and private sector actors are increasingly involved in governance partnerships. Other institutions include informal social norms, conventions or negotiated arrangements, such as those between different groups of fishers surrounding gear use, or between fishers and traders surrounding financing and credit.

States of the Asia-Pacific, as elsewhere, have profoundly different levels of governance capacity and resources devoted to fisheries governance. In many small-scale fisheries across the Asia-Pacific, fisheries are effectively 'self-governed'. In other words, the formal reach of the state has limited purchase, and access to fisheries resources is governed through customary and/or informal institutions that overlap with many of the social institutions described in Chap. 3. For example, in much of the Pacific forms of customary marine tenure can regulate access to marine space along clan lines (Carrier, 1981), or restrict access to waters for a certain period of time (Cohen \& Foale, 2013; Hviding, 1996). Other variations of customary institutions have been well documented for South-East Asia (Ruddle \& Satria, 2010) and South Asia (Coulthard, 2011). An important point to note in this context is that these customary institutions were largely not designed to manage marine resources biologically or ecologically, but to regulate social access (i.e., restricting fishing access to neighbouring groups) (Foale et al., 2011). In contemporary times, many of these customary institutions have been significantly transformed or now coexist with more formal state regulations in conditions of legal pluralism (Bavinck, 2018; Bavinck et al., 2013; Lau et al., 2020).

Historically, the most fundamental model of fisheries governance by states in the Asia-Pacific has been one of resource nationalism (Koch \& Perreault, 2019), where states have explicitly aimed to expand fisheries production and trading. As Campling and Havice (2018: 88) point out in their insightful historical analysis of national seafood production systems, 'national seafood systems promoted volume [of extraction] to ensure the 
reproduction of domestic capital, sustain new industrial societies by providing cheap food for workers and their families, and extend[ed] geopolitical influence'. This process was reflected throughout the vast drive towards industrial expansion in much of Asia in the postwar period, discussed in Chap. 2 (see Butcher, 2004; Christensen, 2014). In the Pacific, a related variety of resource nationalism took place through a domestication model, mostly for tuna. This involved leveraging good natural resources and tariff advantages to compensate for distance from trade routes, lack of infrastructure and high labour costs (Barclay \& Cartwright, 2008).

In many developing countries of the Asia-Pacific there has been a shift towards the concept of 'co-management', centred around the principle of shared responsibility for management between the state and resource users, as well as the participation of other stakeholders such as civil society groups (Evans et al., 2011; Ratner et al., 2012). The underlying objective was to improve both the effectiveness of fisheries resource management and the legitimacy of the state through the active participation of resource users. In practice, co-management models vary on a continuum from centralised, where government undertakes most functions, through consultative and collaborative, to delegated models, where fishers undertake most governance functions (Pomeroy \& Berkes, 1997).

The outcomes of co-management initiatives in the Asia-Pacific are highly variable (Quimby \& Levine, 2018; Sunderlin \& Gorospe, 1997). In Indonesia and the Philippines, for example, co-management is strongly influenced by other social institutions, including kinship, ethnicity, or customary leadership structures, which affect whose interests are prioritised and who effectively participates in decision-making (Eder, 2005; Steenbergen, 2016). Across South-East Asia, the development of comanagement has in many cases been supported by foreign donors, linked in with the rise of community-based management programmes or accompanied by the decentralisation of fisheries management to local governments (Christie et al., 2005; Courtney \& White, 2000). For example, in the Philippines decentralisation led to the demarcation of designated spatial zones for small-scale and industrial fishers (with varying degrees of enforcement). Australia has a centralised model, whereby representatives of industry are involved in advisory groups that meet with fisheries agency staff and review documents but have no decision-making power. Many fishers feel profoundly disempowered in this system (Barclay et al., 2020; King \& O'Meara, 2019). Japan has had a delegated model with some 
fisheries management decisions made through fisheries cooperatives, which during the twentieth century acted well to protect fisher interests, but was not successful at preventing overfishing in key fisheries such as tuna (Barclay \& Koh, 2008).

Common to both richer and poorer countries has been a shift towards EBFM, which aims to replace conventional fisheries science based only on the target species, with understanding of a fishery's effects on the broader ecosystem (Pikitch et al., 2004). For example, some trawl fisheries catch a great deal of other species in addition to the target species, and may damage habitat through dragging trawling gear along the bottom of the sea. A conventional fisheries science approach would look only at the stocks of target species. An EBFM approach would look at all the species being affected by the trawling, and the effect of dragging on the ocean floor. Despite widespread acceptance by governments and scientists internationally since the early 1990s that fisheries should be managed as part of ecosystems (Pikitch et al., 2004), EBFM has largely not been implemented. EBFM constitutes a radical change from existing single species-based management, and it has been unclear how the shift to EBFM may feasibly be achieved (Barclay, 2016). Closely linked with the emergence of marine spatial planning, EBFM is also often associated with the implementation of MPAs. The long-time horizons and variable nature of fishery benefits generated by fish spillover from MPAs, combined with the short-term effects on fishing grounds, mean that the implementation of MPAs has had mixed results for fisher livelihoods (Ban et al., 2019; Gill et al., 2019; Segi, 2014).

More recently has been a shift to what has been broadly termed as 'private' or 'market-based governance', based on the idea of market actors taking a leading role in governing for environmental sustainability (Bush \& Oosterveer, 2019; Groeneveld et al., 2017). This idea has been most notably applied to fisheries in the case of eco-certification and labelling (e.g., the MSC and the sustainable seafood movement). Under this model of governance, transparency is implemented through traceability documentation (Bailey et al., 2016). While the direct involvement of the private sector as leading actors in fisheries governance is a relatively new phenomenon, it builds on the logic of economic rationalism, or neoliberalism, that has driven much fisheries governance for several decades, especially in richer countries.

Neoliberalism as a particular type of governance, especially of economic activity, has become increasingly widespread since the 1980s. Neoliberalism 
is an all-embracing kind of term, used in some cases to refer to specific policy mixes involving deregulation, privatisation and use of market mechanisms in the policy sphere, but also to refer more diffusely to a form of governmentality (McCormack, 2017a). In marine governance neoliberalism has taken shape from a particular vision dating from the 1950s of oceans as commons with inherent problems of overfishing and overcapacity (Mansfield, 2004). In this logic it is human nature to overexploit commons resources, to competitively race to fish and innovate technologically in that race to fish, causing both overfishing and overcapacity (McCormack, 2017a). Converting ocean commons to private property and then using market mechanisms to allocate access to the resource is seen as a way to harness the profit motive to achieve conservation objectives and improve economic efficiency (Mansfield, 2004; McCormack, 2017a). Public access to resources has been limited by turning commons into private property that can be controlled and traded (Mansfield, 2007). In fisheries management neoliberal privatisation and market mechanisms have been brought together in the form of individual transferable quotas (ITQs) (Mansfield, 2004; McCormack, 2017a, 2017b; Pinkerton, 2017).

ITQs build on existing foundations in fisheries science of stock assessments generating a TAC-an amount of the target species that may be harvested annually. In ITQs the TAC is divided into quota shares, which are often allocated among fishers according to catch history or levels of investment. Each quota holder is allowed to catch up to the limit of its quota (usually a tonnage). This is called an 'output' control on fisheries, in that the control is on what comes out of the fishery, as opposed to 'input' controls on what goes into a fishery, such as controls on gear (e.g., net mesh size) or temporal limits to the fishing season. Fishing quotas may be traded. Less efficient operators tend to sell their quota to more efficient operators in a process that reduces the overall number of quota owners and increases the profitability of the quota owners who remain. However, this does not necessarily mean fishers themselves experience economic improvements. For example, the British Columbia halibut fishery is often hailed as an ITQ economic success, but 79 per cent of the quota was leased-most fishers did not own quota themselves. For quota-leasing fishers the economics of operational and leasing costs in relation to fish prices was much less favourable (Pinkerton \& Edwards, 2009).

ITQ proponents argue that having property rights in fisheries encourages quota owners to see their wealth as dependent on the health of fish stocks, therefore, encouraging stewardship of the resource (McCormack, 
2017a). There is no empirical evidence that ITQs are correlated with or cause norm change regarding environmental stewardship (Hoshino et al., 2019). Indeed, ITQ systems have been found to encourage high grading and dumping, poaching and under-reporting (McCormack, 2017b; Pinkerton, 2017).

The neoliberal ITQ model has not universally been seen as a good template for fisheries management. For example, in Japan the preferred model has been for co-management with fisheries cooperatives, whereby the cooperatives were largely responsible for controlling the fishing activities of members (Barclay \& Epstein, 2013; Barclay \& Koh, 2008). The Japanese co-management with cooperatives model has not been particularly successful at curbing overfishing, with two infamous examples being whaling and bluefin tuna fisheries (Epstein \& Barclay, 2013), but it has arguably been effective in terms of managing conflicts between fishers (Matsuda, 1987) and preserving fishing livelihoods in rural parts of Japan (Barclay \& Koh, 2008). Nevertheless, neoliberal fisheries management ideas have eventually started to infiltrate Japan's fisheries management and into that of many other countries that have hitherto resisted ITQs (McCormack, 2017a: 32). Yet, at the same time, challenges to neoliberalism in fisheries policy are also gaining ground around the world (Pinkerton, 2017).

ITQs may only be feasible in wealthy countries, because they require a high level of state involvement in ascertaining TACs and administering quota systems. Moreover, ITQs embody a 'wealth' rather than a 'welfare' orientation regarding fisheries (Béné et al., 2010). ITQs explicitly aim to accumulate the wealth of a fishery among fewer participants (Hoshino et al., 2019; Pinkerton, 2017). Even early studies noted that ITQs tend to concentrate ownership, causing smaller operators to leave the industry (Connor \& Alden, 2001; McCay, 1995). Studies have found there is often decreased employment in fisheries where ITQs are implemented, and that high quota prices act as a barrier preventing fishers from becoming quota owners (Hoshino et al., 2019).

In this introductory section of the chapter we have briefly highlighted several of the most prominent models for fisheries governance that are widely adopted around the world, such as customary institutions, resource nationalism, co-management, EBFM, market-based fisheries governance and neoliberalism. An important point to note about all governance models is that they are not neutral technical interventions, but represent particular ideas about the world, based on valuations of people and the 
environment ( $\mathrm{Li}, 2007)$. As formal regulations become implemented in practice, they interact with other social institutions such as culture and social norms that, in turn, have been generated over time. In this chapter we consider two cases of different governance models operating in very different contexts and trace their implications for fishing livelihoods.

\section{Fisheries Governance in Australia}

Fisheries governance in Australia until the end of the 1980s was largely open access, aimed at generating jobs and increasing food supplies. There was overfishing and had been since the earliest days of colonisation (Wilkinson, 1997). For example, settlers in South Australia harvested oysters so excessively they wiped out many oyster beds in the 1800s (WallaceCarter, 1987). In line with a general move towards ecologically sustainable development around 1990, fisheries management moved towards biologically sustainable fishing, preventing overfishing. In terms of economic goals for fisheries, the Australian Government (2019) aims to 'maximise the net economic return to the Australian community' (Commonwealth of Australia, 2017: 2) from the use of fisheries resources, and to have 'cost recovery'-meaning have fishers pay for fisheries management (Patterson et al., 2020). Australian fisheries governance since the 1990s has favoured profitable fisheries over other economic considerations such as job creation, and implemented ITQs fairly widely.

One of the prominent models of fishing in Australia has been that of small-scale fishing using a single boat with diversified methods across species, gear, locations and markets, to respond to fluctuations in environmental and market conditions (Minnegal \& Dwyer, 2008; Voyer et al., 2016) (see Fig. 4.1). It was a viable business model to manage the inherent risks in near-shore and estuarine fisheries that have great natural variation in stock availability (Barclay et al., 2020; Voyer et al., 2016). By the late 1990s fisheries management in Australia had moved in a direction that discouraged this kind of fishing in favour of larger-scale specialist operations (Minnegal \& Dwyer, 2008). This was part of a wave of similar policies pursued internationally to discourage smaller diversified operators in favour of larger-scale specialist operators (Hilborn et al., 2001). Diversified small operators are generally not as efficient as larger operations with equipment specialised for a specific fishery, and Australian fisheries management has worked to reduce fleet sizes by pushing out inefficient operators (Connor \& Alden, 2001). 


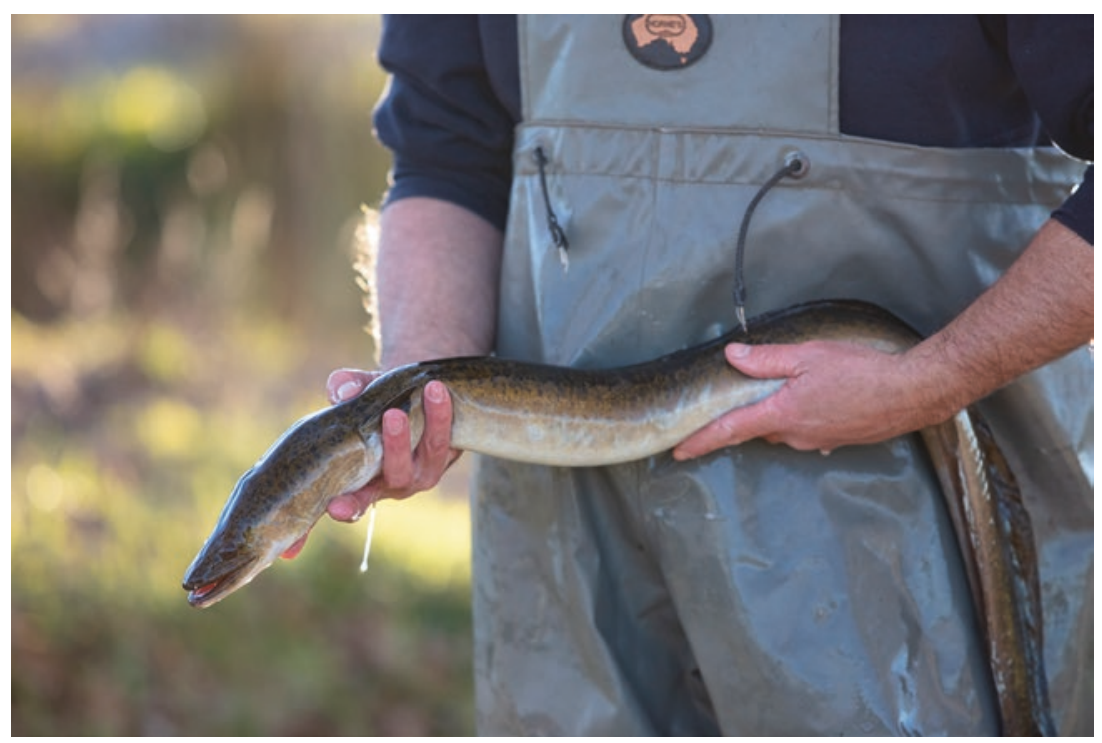

Fig. 4.1 Fisher with freshly caught eel in Victoria, Australia. (Photo credit: Impress Photography)

Small-scale diversified fishers were also discouraged because of the ecologically sustainable development approach wanting to reduce 'latent capacity' or 'latent effort'. Diversified operators keep rights in fisheries they do not often use so that when the environmental and market conditions suit they can work in that fishery, but most of the time they do not. In practical terms there is not overfishing because the rights are not fully used, but there is the potential that if fishers did fully use all of their rights at once there could be overfishing. As fisheries managers want to reduce this risk, they have moved to get rid of little-used rights (Barclay et al., 2020; Minnegal \& Dwyer, 2008).

Regulation in favour of economic efficiency and eliminating latent effort has, thus, discouraged diversified fishing. Alongside the regulation has been a discourse that delegitimises fishing operations that are low profit. The concepts of net economic returns to the community and cost recovery mean that fisheries 'should' be able to pay a resource rent back to government and cover fisheries management costs. If they are not profitable enough to do this then it is argued that they should not have access 
to the resource. Fishers who are not very profitable have been stigmatised as 'lifestyle' fishers rather than as 'business-oriented' fishers. Simply supporting a family or employing oneself in one's chosen vocation is no longer seen as a legitimate use of commons fisheries resources (Minnegal \& Dwyer, 2008; Voyer et al., 2016).

Australian fisheries management since the 1990s has been neoliberal, working towards privatising resource access rights in ITQs and allocating them through market mechanisms (Bichler et al., 2019; Organisation for Economic Co-operation and Development, n.d.) as the best way to meet the objectives of ecologically sustainable development and economic efficiency in Commonwealth and state fisheries legislation (Commonwealth of Australia, 2017; Minnegal \& Dwyer, 2008). Not all fisheries were put under ITQ management in the 1990s or subsequently, but even non-ITQ fisheries were strongly influenced by the governance mode prioritising the prevention of overfishing over the social benefits of fisheries, and favouring profitable operating styles over ones that generate more jobs.

Some large-scale, high-value fisheries have flourished with this type of management. For example, the highly migratory southern bluefin tuna were thoroughly overfished internationally by the 1980s. Prior to the fishery coming under quota management, 136 fishing boats were in the southern bluefin tuna fishery across three Australian states. ITQs were introduced into the southern bluefin fishery in 1984 and well over half of the boats left the fishery within two years (Campbell et al., 2000). By the mid-1990s all southern bluefin quota had been consolidated into $13 \mathrm{com}$ panies based in Port Lincoln in South Australia. There the industry developed a ranching system that enabled the fishery to recover economically, becoming so successful that the regional economy around Port Lincoln was boosted by the industry. Port Lincoln became famous for having a high per-capita number of millionaire 'tuna barons', but the industry also generated a great deal of jobs. In the financial year 2016-2017 tuna farming in Port Lincoln and flow-on activities such as processing and transport amounted to 856 full-time equivalent jobs, and each of these jobs is estimated to have created an additional 2.13 jobs elsewhere in the state economy (Econsearch, 2018).

However, in other Australian ITQ fisheries fishers' livelihoods have not fared so well. For example, in Tasmania's abalone fishery much of the quota is owned by investors who lease the quota to fishers for harvesting. Profits in the fishery go to the quota owners rather than the fishers, and the fishers have no security of access to the resource. Quota prices are 
prohibitively high, which combined with quota rarely coming onto the market means a barrier to new entrants (Hoshino et al., 2019).

The ITQ model is now being rolled out in lower-value, small-scale, multi-species, multi-gear fisheries that have made up the majority of fishing in parts of Australia, and many in the industry are concerned about negative effects on livelihoods. ITQs were implemented broadly in New South Wales from 2017. The effects on income and employment are not clear because no data are collected on these aspects of fisheries in most of Australia, but a majority of fishers say the reforms have damaged their livelihoods, and their wellbeing appears to have suffered from the reform process (Barclay et al., 2020). Fishers in Queensland and South Australia facing imminent ITQ reforms similarly fear that many operators will be forced out of the industry (McClean, Voyer, et al., 2019b; Sutton Sutton, 2020).

A neoliberal approach to fisheries, including ITQs, is also at odds with the values, rights, knowledge systems and social practices of Indigenous peoples in Australia (Lalancette, 2017; Schnierer \& Egan, 2015). ITQs have been embedded into Māori fishing rights by the New Zealand Government, which has led to widening income inequality between general tribe members and those with decision-making rights over quota, and reduced Māori people's rights to fish as a livelihood (McCormack, 2013).

Over the same time period as the Australian Government took a neoliberal approach to fisheries management and shifted from supporting livelihoods to preventing overfishing, conservationist perspectives have also permeated the Australian public consciousness more broadly. Science communication and conservation organisation media campaigns spread awareness of the problems of overfishing internationally. Images of overfishing were received by the Australian public in ways that resulted in a cultural devaluing of fisheries as a livelihood. Fishing, previously somewhat stigmatised because of its working-class status, has become even more stigmatised, with fishers often treated by the public as environmental 'rapers and pillagers' (Kearney, 2013).

Australian fishers are sometimes spat on and have rocks thrown at them, their vehicles and fishing equipment are vandalised, and strangers yell at them, claiming that they are destroying the marine environment (King, 2018; Voyer et al., 2016). Some people fish at night to avoid encounters with the public at the wharf, and build high fences to hide fishing gear in their yards. Some children of fishers lie at school about their parents' jobs (Voyer et al., 2016). There is a budding food localism movement, but in 
general fishers are not valued in Australian society as food producers. Over 70 per cent of seafood consumed in Australia is imported (Kearney, 2013).

In Australia the public has been primed with the narrative 'they take all the fish' by the recreational fishing movement. Recreational fishing has long been a popular pastime in Australia, and complaints by recreational fishers that their sport is ruined by professional fishers taking too many fish were published in Sydney newspapers as early as the 1860s (Clark, 2017). Since the 1970s recreational fishing has grown in popularity and since the 2000s recreational fishing lobby groups have leveraged their large constituency to wield a great deal of political influence (Voyer et al., 2017).

Lack of public support for professional fishing, environmental movements focused on establishing reserves where fishing is banned, and recreational fishing lobbying activities have caused professional fishers to lose access to fishing grounds. In 2001 professional fishers had access to 113 water bodies in New South Wales, of which 24 supplied 95 per cent of all fish caught professionally in the state. By 2012 professional fishing was banned or restricted in 15 of those 24 , due to zoning of those water bodies as 'recreational fishing havens' or MPAs (Stevens et al., 2012: 5). In Victoria the recreational fishing lobby has succeeded in having the state government ban professional fishing in places such as Port Philip Bay, despite the scientific evidence indicating that those fisheries were biologically sustainable, and with no evidence that removing professional fishing would improve recreational fishing outcomes (King \& O'Meara, 2019).

What will happen to fishing livelihoods in Australian in the future? Not many young people are willing or able to enter the fishing industry for a range of reasons outlined above - the high cost of buying quota, lost fishing grounds, the stigma fishing has acquired as environmentally damaging - and other reasons to do with difficult regulations and high production costs (Abernethy et al., 2020; Barclay et al., 2020; King et al., 2019; Minnegal \& Dwyer, 2008; Shaw et al., 2011; Voyer et al., 2016). Fishing livelihoods remain but are increasingly in corporate operations rather than the small-scale diverse fisheries that characterised much Australian fishing in the past. There is also a group of family businesses capitalising on growing food localism among consumers and moving up the value chain into direct sales, for example, through farmers markets (Abernethy et al., 2020; Voyer et al., 2016). With market disruptions due to COVID-19 there has been reorientation of export value chains to domestic markets, and 
interest in local production of food has strengthened. Therefore, there is hope for fishers who weather the COVID-19 storm and the longer-term pressures of neoliberal governance.

\section{Fisheries Governance in Indonesia}

Fisheries governance in Indonesia is very different to that of Australia. Indonesia is a much larger producing state, the second largest fishery producer by volume in the world after China, whereas Australia is around fiftieth. Indonesia's fisheries are diverse, mostly informal and small scale, spread across thousands of beaches, ports and inland waterways. Fishing is foundational to the food supply and livelihoods of coastal communities in Indonesia's very large population. Around 12 per cent are below the poverty line and 27 per cent are characterised as being vulnerable to slipping into poverty. Poverty rates are disproportionately high in fishing communities (World Bank, 2015). As a middle-income country Indonesia has less government resources available for fisheries management than highincome countries like Australia.

For centuries fishing has been a mainstay livelihood activity along the vast stretches of coast and inland waterways of the islands that became the modern state of Indonesia. This included food for local consumption as well as the trade in dried marine products, such as trepang (dried sea cucumbers) that have long been traded around South-East Asia and to China. As in the rest of South-East Asia, European colonial arrangements and then Japanese fishing companies were influential in the establishment of industrial fishing in the twentieth century.

In the 1970s Japan retreated somewhat from international fishing, due to rising wages and other production costs in the Japanese fleet, including the advent of fishing access payments due to the establishment of $200 \mathrm{~nm}$ EEZs under UNCLOS (Barclay, 2014). This left space for Indonesian industrial fishing companies to develop. In 1975 the Indonesian Government created the tuna longline company Perikanan Samodra Besar (known also as PSB or PERSERO), which early on worked with the Japanese fleet, but then moved on to operate independently. In the 1980s, the company expanded, and the Indonesian Government financially supported other industrial fishing companies (Morgan \& Staples, 2006).

State governance of fisheries in Indonesia has largely been oriented to industrial fishing and processing, taking a resource nationalist approach of increasing production to increase economic benefits. Indonesia's support 
for domestic industrial fisheries was part of a tide of resource nationalism among former colonies in the 1970s. Newly decolonised states hoped to use control over their own resources to establish a New International Economic Order, wherein former colonies were not subordinated to former coloniser states. They took inspiration from what OPEC countries managed to achieve with their oil resources. In fisheries this coincided with the negotiations that led to UNCLOS, with states taking economic control of waters to $200 \mathrm{~nm}$ from their coast (i.e., EEZs), meaning distant water fishing states like Japan had to negotiate access to fishing grounds they had previously used for free. Therefore, in fisheries, the 1970s trend for resource nationalism took the form of developing domestic industrial fisheries, requiring distant water fishing states to invest in joint ventures and onshore processing, or to pay fees in return for access to EEZs (Schurman, 1998).

Indonesia's 2004 Fisheries Act has nine objectives for fisheries management, one of which is about guaranteeing the sustainability of fish resources, and the other eight are about using the resources for economic goals, including improved living standards for small-scale fishers, government revenue, population nutrition, and supporting industrial fishing and processing. However, to date, Indonesian state management of fisheries has mainly facilitated industrial expansion in fishing and processing, rather than monitoring fish stocks or applying limits to fisheries for the purpose of sustaining fish stocks (California Environmental Associates [CEA], 2018; Sunoko \& Huang, 2014). The expansion of fishing has meant more jobs on fleets, in processing and in fish trading. It is difficult to say exactly how many people have incomes from fishing in Indonesia, but it is likely in the millions. For example, in the area around Bitung, which is a major industrial tuna fishing and processing hub in Eastern Indonesia, it is estimated there are at least 12,000 small-scale tuna fishers (Sukarsih et al., 2019) (see Fig. 4.2). There would be thousands more on the industrial fleet and in the processing plants.

Indonesian government capacity to monitor and regulate fisheries is limited as a developing country with a huge population and enormous fisheries spread over thousands of islands, as well as a complex governance system between national, provincial and municipal level agencies (Cabral et al., 2018). Overall fisheries policy and licensing for vessels over $30 \mathrm{GT}$, and management of maritime areas outside $12 \mathrm{~nm}$, sits with national offices of the Ministry of Marine Affairs and Fisheries. Areas within $12 \mathrm{~nm}$ are the responsibility of provincial government offices of the Ministry. 


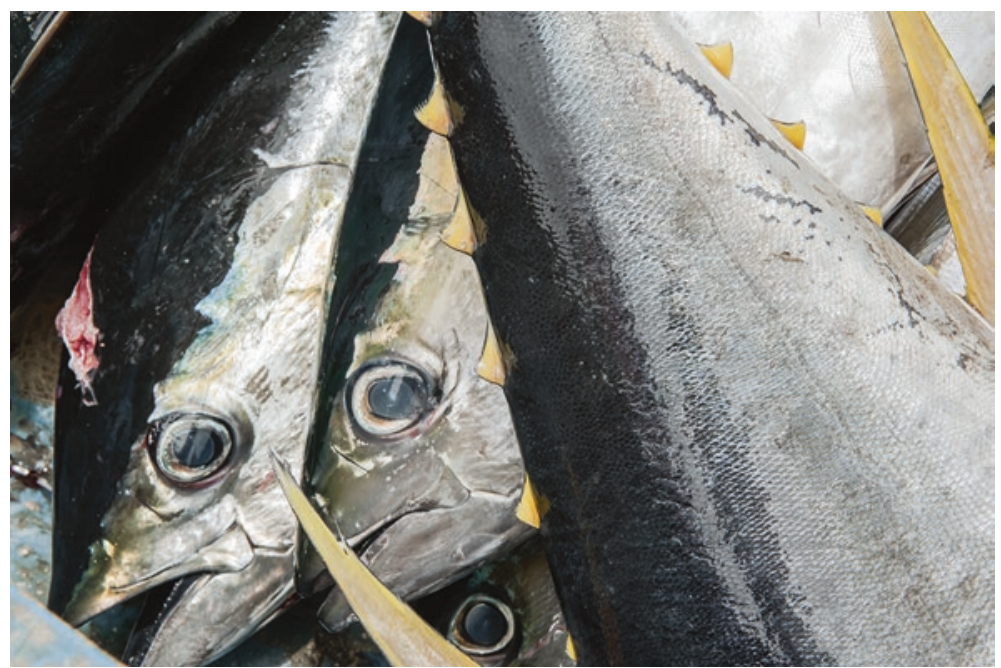

Fig. 4.2 Freshly caught yellowfin tuna. (Photo credit: Katherine Jack)

Small vessels must be registered but do not pay license fees. Indonesia has had limited control over fisheries and poor fisheries data, in part because of the huge diverse fleet operating from thousands of mostly informal landing sites (Cabral et al., 2018; CEA 2018). Given that Indonesia is such a significant fishing country, since the 1990s other countries sharing migratory stocks such as tuna have worked with Indonesia through regional fisheries management organisation ('RFMO') processes to try to improve data (Hanich et al., 2010).

Indonesian fisheries governance shifted somewhat with the appointment of Minister of Fisheries Susi Pudjiastuti (2014-2019). With a dual agenda to prevent illegal, unreported and unregulated (IUU) fishing and to replace foreign investment, Minister Susi presided over the implementation of policies that saw Filipino fishers and vessels leave Indonesian waters, including exploding confiscated fishing vessels (Cabral et al., 2018; McClean, Barclay, et al., 2019a). In addition to removing foreign vessels, the anti-IUU measures also decreased the amount of tuna from Indonesian waters being sent overseas for processing, with the aim to increase the supply of fish for Indonesian processors-although in the short term the removal of Filipino vessels caused fish supplies for the industrial processors to drop (McClean, Barclay, et al., 2019a). Prior to Susi's tenure, the 
government largely neglected small-scale fisheries, and here again Susi broke new ground. She announced that the Filipino large-scale tuna fishing vessels banned from 2014 would be replaced with 3325 new small- to medium-scale vessels to be built in Indonesia with government funding and given to Indonesian fishers (McClean, Barclay, et al., 2019a).

Minister Susi's tenure was intensely controversial in the Indonesian seafood industry, but she had popular support and remained in the post for five years. She was eventually replaced in 2019 by Edhy Prabowo, who was less obvious in supporting any particular governance direction. In November 2020 Minister Prabowo was arrested for alleged corruption regarding exports of lobster seed (Dao, 2020).

The Indonesian Government has not so far implemented neoliberal fisheries management tools such as ITQs. It does not have TACs, which are foundational for ITQs. The Ministry of Marine Affairs and Fisheries continues to work towards strengthening data collection and stock assessment, aiming to develop harvest strategies for key fisheries such as tuna (Hoshino et al., 2020). In line with fisheries management internationally, Indonesia is also moving towards ecosystem-based management, with comanagement between government and industry (Muawanah et al., 2018).

There has been some adoption of certification for export markets, with effects that constitute a limited form of market-based governance. One issue with market-based certification is that it requires extensive documentation and verification at each stage of the supply chain. Such 'audit culture' was developed in high-income countries and is highly unsuited to small-scale informal Indonesian fisheries, where documentation is not a normal part of life (Bush et al., 2013). Therefore, small-scale fishers entering into certification require intermediaries to assist with the documentation; these are usually the trading companies that buy the fish for export.

On the biological front, several fisheries are in MSC assessment or are moving towards it as part of fishery improvement programmes, which are mostly supported by philanthropic organisations (Levine et al., 2020). Some small-scale handline tuna fisheries exporting to US markets entered fair-trade certification in the mid-2010s. Fair-trade fishers are paid a price premium as a community development fund, which can be used for mutually beneficial things such as fishing safety equipment or community projects. For the purposes of traceability catches are documented, which creates an opportunity to monitor catches (previously small-scale catches were not recorded). Over 700 fishers around Ambon now provide catch data that feed into provincial-level fisheries data collection used in 
decision-making Fisheries Co-Management Committees (McClean, Barclay, et al., 2019a). In recent years the use of forced labour (slavery) in Indonesian fisheries and seafood processing has become a prominent issue but as yet there is no market-based measure that effectively tackles labour conditions.

Diverse forms of customary practices and laws relating to marine spaces at the local level remain important institutions across the country. For example, among Sama-Bajau fishers there are prohibitions against harming or hunting whale sharks (Stacey et al., 2012). In Aceh Province there are local 'sea commanders' (panglima laot) who are responsible for enforcing laws relating to the sea, such as dispute resolution among fishers, access to fishing grounds, and management of mooring sites and ports (Nurasa et al., 1993; Wilson \& Linkie, 2012). In other parts of Indonesia, such as in Maluku and Sulawesi, customary laws such as spatial and temporal closures (e.g., for trochus) of marine resources (sasi) have been well documented (Satria \& Adhuri, 2010; Thorburn, 2000). Typically, such customary practices and laws form part of wider social institutions, and have varying levels of codification, recognition by government, and enforcement. They can be highly dynamic and, increasingly, environmental NGOs are assessing and harnessing these customary practices and laws for their potential to contribute to marine conservation and sustainable resource management (McLeod et al., 2009; Zerner, 1994).

\section{Conclusion}

Different modes of fisheries governance have evolved across the AsiaPacific at multiple scales of governance. Highly diverse, they represent competing logics of how to manage people and resources. Customary forms of governance have long regulated access to marine resources, embedded within the wider social worlds of culture and social relationships. As the power and capacity of many states grew after World War II, resource nationalism became the default policy for many states in the AsiaPacific, as they sought to extract the maximum benefits from their oceans through extensive support for commercial fishing industries. More recently, concerns about overfishing and ecological degradation have also become key factors underlying fisheries governance in many countries, as have forms of governance that seek to harness, and maximise, the financial aspects of fisheries. Many high-income countries have adopted neoliberal fisheries policy approaches, which focus on aggregate generation of wealth, 
rather than focusing on welfare, considering the distribution of livelihoods across groups in society. In contrast, movements that emphasise the roles, knowledge, expertise and rights of local communities and fishers have manifested in forms of governance such as co-management and human rights-based approaches (Allison et al., 2012; Jentoft et al., 2017).

There is an implicit assumption in some of the fisheries literature that policymaking is a technical process, that it is possible to attain the right outcomes if only the right governance institutions are put in place. Yet, policies are always implemented in particular contexts - they interact with pre-existing forms of governance, and with the social and politicaleconomic contexts discussed in Chaps. 2 and 3. Understanding how the policymaking process itself evolves is just as significant for assessing outcomes as the particular contents of any policy. For example, in the Australian case, the intersection of recreational fishing, conservation discourse and neoliberal fisheries management converged to govern fishing livelihoods in particular ways.

Ultimately, governance institutions that unfold in particular contexts shape the kinds of livelihoods that are on offer and to whom. In the Indonesian case, state regulation has meant that Filipino fishers were pushed out by new regulations, while informal and customary institutions also enable some groups to fish and not others. Certification initiatives require collaborators to handle the paperwork, which leads to fishers being dependent on those partners, and fishers who do not have such partnerships are excluded from certification (McClean, Barclay, et al., 2019a). In the Australian case, the neoliberal approach to governing fisheries has led away from small-scale diversified fishing livelihoods towards more corporate, specialised operations.

In the context of the blue economy-where interest by state, market and civil society actors in the governance and use of the oceans is rapidly expanding (Voyer et al., 2018) - the influence of different ideas about governance on fishing livelihoods will only increase. Fishing livelihoods have been under pressure to demonstrate their environmental sustainability and the transparency and traceability of their operations, and to comply with intensified environmental governance such as MPAs. As the generation of economic wealth and the protection of the natural environment emerge as powerful themes in the blue economy, ensuring that fishing livelihoods are adequately represented and included in governance is a crucial challenge for policymakers. 


\section{REFERENCES}

Abernethy, K., Barclay, K., McIlgorm, A., Gilmour, P., McClean, N., \& Davey, J. (2020). Victoria's fisheries and aquaculture: Economic and social contributions. Research project. FRDC 2017-092. University of Technology Sydney.

Allison, E. H., Ratner, B. D., Åsgård, B., Willmann, R., Pomeroy, R., \& Kurien, J. (2012). Rights-based fisheries governance: From fishing rights to human rights. Fish and Fisheries, 13(1), 14-29. https://doi.org/10.1111/j.14672979.2011.00405.x

Australian Government. (2019). Cost recovery implementation statement 2018-19. Australian Fisheries Management Authority. Retrieved February 5, 2021, from https://www.afma.gov.au/sites/default/files/uploads/2018/06/AFMACost-Recovery-Implementation-Statement-CRIS-2018-19_.pdf

Bailey, M., Bush, S. R., Miller, A., \& Kochen, M. (2016). The role of traceability in transforming seafood governance in the global south. Current Opinion in Environmental Sustainability, 18, 25-32. https://doi.org/10.1016/j. cosust.2015.06.004

Ban, N. C., Gurney, G. G., Marshall, N. A., Whitney, C. K., Mills, M., Gelcich, S., Tran, T. C., et al. (2019). Well-being outcomes of marine protected areas. Nature Sustainability, 2(6), 524-532. https://doi.org/10.1038/ s41893-019-0306-2

Barclay, K. (2014). History of industrial tuna fishing in the Pacific Islands. In J. Christensen \& M. Tull (Eds.), Historical perspectives of fisheries exploitation in the Indo-Pacific (pp. 153-171). MARE Series, Vol. 12. Springer.

Barclay, K. (2016). Futures of governance: Ecological challenges and policy myths in tuna fisheries. In J. P. Marshall \& L. H. Connor (Eds.), Environmental change and the world's futures: Ecologies, ontologies and mythologies (pp. 65-80). Routledge.

Barclay, K., \& Cartwright, I. (2008). Capturing the wealth from tuna: Case studies from the Pacific. ANU Press.

Barclay, K., \& Epstein, C. (2013). Securing fish for the nation: Food security and governmentality in Japan. Asian Studies Review, 37(2), 215-233. https://doi. org/10.1080/10357823.2013.769498

Barclay, K., \& Koh, S.-H. (2008). Neoliberal reforms in Japan's tuna fisheries? A history of government-business relations in a food-producing sector. Japan Forum, 20(2), 139-170. https://doi.org/10.1080/09555800802047475

Barclay, K., Davila, F., Kim, Y., McClean, N., \& Mcilgorm, A. (2020). Economic analysis and social and economic monitoring following the NSW commercial fisheries business adjustment program. Institute for Sustainable Futures, University of Technology Sydney. Retrieved February 5, 2021, from https://www.dpi. nsw.gov.au/_data/assets/pdf_file/0007/1256128/Economic-analysis-andSocial-and-Economic-monitoring-following-the-NSW-Commercial-FisheriesBusiness-Adjustment-Program.pdf 
Bavinck, M. (2018). Legal pluralism, governance, and the dynamics of seafood supply chains-Explorations from South Asia. Maritime Studies, 17(3), 275-284. https://doi.org/10.1007/s40152-018-0118-4

Bavinck, M., Johnson, D., Amarasinghe, O., Rubinoff, J., Southwold-Llewellyn, S., \& Thomson, K. T. (2013). From indifference to mutual support-A comparative analysis of legal pluralism in the governing of south Asian fisheries. The European Journal of Development Research, 25(4), 621-640. https://doi. org/10.1057/ejdr.2012.52

Béné, C., Hersoug, B., \& Allison, E. H. (2010). Not by rent alone: Analysing the pro-poor functions of small-scale fisheries in developing countries. Development Policy Review, 28(3), 325-358. https://doi.org/10.1111/j.1467-7679. 2010.00486.x

Bichler, M., Fux, V., \& Goeree, J. K. (2019). Designing combinatorial exchanges for the reallocation of resource rights. Proceedings of the National Academy of Sciences of the United States of America, 116(3), 786-791. https://doi. org/10.1073/pnas.1802123116

Bromley, D. W. (1992). The commons, common property, and environmental policy. Environmental and Resource Economics, 2(1), 1-17. https://doi. org / $10.1007 / \mathrm{BF} 00324686$

Bromley, D. W., \& Cernea, M. M. (1989). The management of common property natural resources: Some conceptual and operational fallacies. Discussion Paper no. 57. World Bank.

Bush, S. R., \& Oosterveer, P. (2019). Governing sustainable seafood. Routledge.

Bush, S. R., Toonen, H., Oosterveer, P., \& Mol, A. P. J. (2013). The 'devils triangle' of MSC certification: Balancing credibility, accessibility and continuous improvement. Marine Policy, 37(1), 288-293. https://doi.org/10.1016/ j.marpol.2012.05.011

Butcher, J. G. (2004). The closing of the frontier: A history of the marine fisheries of Southeast Asia, c. 1850-2000. Institute of Southeast Asian Studies.

Cabral, R. B., Mayorga, J., Clemence, M., Lynham, J., Koeshendrajana, S., Muawanah, U., Costello, C., et al. (2018). Rapid and lasting gains from solving illegal fishing. Nature Ecology \& Evolution, 2(4), 650-658. https://doi. org/10.1038/s41559-018-0499-1

California Environmental Associates. (2018). Trends in marine resources and fisheries management in Indonesia: A review. CEA. Retrieved September 30, 2020, from https://www.packard.org/wp-content/uploads/2018/08/IndonesiaMarine-Full-Report-08.07.2018.pdf

Campbell, D., Brown, D., \& Battaglene, T. (2000). Individual transferable catch quotas: Australian experience in the Southern Bluefin tuna fishery. Marine Policy, 24(2), 109-117. https://doi.org/10.1016/S0308-597X(99)00017-2

Campling, L., \& Havice, E. (2018). The global environmental politics and political economy of seafood systems. Global Environmental Politics, 18(2), 72-92. https://doi.org/10.1162/glep_a_00453 
Carrier, J. G. (1981). Ownership of productive resources on Ponam Island, Manus province. Journal. Société des Océanistes, 37(72), 205-217. https://doi. org/10.3406/jso.1981.3061

Christensen, J. (2014). Unsettled seas: Towards a history of marine animal populations in the central Indo-Pacific. In J. Christensen \& M. Tull (Eds.), Historical perspectives of fisheries exploitation in the Indo-Pacific (pp. 13-39). MARE Series, Vol. 12. Springer.

Christie, P., Lowry, K., White, A. T., Oracion, E. G., Sievanen, L., Pomeroy, R., Pollnac, R., et al. (2005). Key findings from a multidisciplinary examination of integrated coastal management process sustainability. Ocean \& Coastal Management, 48(3-6), 468-483. https://doi.org/10.1016/j. ocecoaman.2005.04.006

Clark, A. (2017). The catch: The story of fishing in Australia (1st ed.). National Library of Australia.

Cohen, P. J., \& Foale, S. J. (2013). Sustaining small-scale fisheries with periodically harvested marine reserves. Marine Policy, 37, 278-287. https://doi. org/10.1016/j.marpol.2012.05.010

Commonwealth of Australia. (2017). Commonwealth fisheries policy statement. Department of Agriculture and Water Resources. Retrieved February 5, 2021, from https://www.agriculture.gov.au/sites/default/files/sitecollectiondocuments/fisheries/domestic/cwlth-fisheries-policy-statement.pdf

Connor, R., \& Alden, D. (2001). Indicators of the effectiveness of quota markets: The south east trawl fishery of Australia. Marine and Freshwater Research, 52(4), 387-397. https://doi.org/10.1071/MF99164

Coulthard, S. (2011). More than just access to fish: The pros and cons of fisher participation in a customary marine tenure (Padu) system under pressure. Marine Policy, 35(3), 405-412. https://doi.org/10.1016/j.marpol. 2010.11 .006

Courtney, C. A., \& White, A. T. (2000). Integrated coastal management in the Philippines: Testing new paradigms. Coastal Management, 28(1), 39-53. https://doi.org/10.1080/089207500263639

Dao, T. (2020, December 2). Indonesian fisheries minister arrested in baby lobster export probe. SeafoodSource. Retrieved February 5, 2021, from https://www. seafoodsource.com/news/supply-trade/indonesian-fisheries-ministerarrested-in-baby-lobster-export-probe

Econsearch. (2018). The economic contribution of aquaculture in the south Australian state and regional economies, 2016/17. Adelaide, South Australia. Retrieved December 3, 2020, from https://pir.sa.gov.au/aquaculture/ publications/_nocache

Eder, J. F. (2005). Coastal resource management and social differences in Philippine fishing communities. Human Ecology, 33(2), 147-169. https://doi. org/10.1007/s10745-005-2430-Z 
Epstein, C., \& Barclay, K. (2013). Shaming to 'green': Australia-Japan relations and whales and tuna compared. International Relations of the Asia-Pacific, 13(1), 95-123. https://doi.org/10.1093/irap/lcs019

Evans, L., Cherrett, N., \& Pemsl, D. (2011). Assessing the impact of fisheries comanagement interventions in developing countries: A meta-analysis. Journal of Environmental Management, 92(8), 1938-1949. https://doi.org/10.1016/ j.jenvman.2011.03.010

Foale, S., Cohen, P., Januchowski-Hartley, S., Wenger, A., \& Macintyre, M. (2011). Tenure and taboos: Origins and implications for fisheries in the Pacific. Fish and Fisheries, 12(4), 357-369.

Gill, D. A., Cheng, S. H., Glew, L., Aigner, E., Bennett, N. J., \& Mascia, M. B. (2019). Social synergies, tradeoffs, and equity in marine conservation impacts. Annual Review of Environment and Resources, 44, 347-372. https:// doi.org/10.1146/annurev-environ-110718-032344

Groeneveld, R. A., Bush, S. R., \& Bailey, M. (2017). Private governance of ocean resources. In P. A. L. D. Nunes, L. E. Svensson, \& A. Markandya (Eds.), Handbook on the economics and management of sustainable oceans (pp. 416-428). Edward Elgar Publishing.

Hall, D., Hirsch, P., \& Li, T. M. (2011). Powers of exclusion: Land dilemmas in Southeast Asia. University of Hawai'i Press.

Hanich, Q., Tsamenyi, M., \& Parris, H. (2010). Sovereignty and cooperation in regional Pacific tuna fisheries management: Politics, economics, conservation and the vessel day scheme. Australian Journal of Maritime and Ocean Affairs, 2(1), 2-15. https://doi.org/10.1080/18366503.2010.10815650

Hilborn, R., Maguire, J.-J., Parma, A. M., \& Rosenberg, A. A. (2001). The precautionary approach and risk management: Can they increase the probability of successes in fishery management? Canadian Journal of Fisheries and Aquatic Sciences, 58(1), 99-107. https://doi.org/10.1139/f00-225

Hoshino, E., van Putten, I., Pascoe, S., \& Vieira, S. (2019). Individual transferable quotas in achieving multiple objectives of fisheries management. Marine Policy, 113, 103744. https://doi.org/10.1016/j.marpol.2019.103744

Hoshino, E., Hillary, R., Davies, C., Satria, F., Sadiyah, L., Ernawati, T., \& Proctor, C. (2020). Development of pilot empirical harvest strategies for tropical tuna in Indonesian archipelagic waters: Case studies of skipjack and yellowfin tuna. Fisheries Research, 227, 105539. https://doi.org/10.1016/ j.fishres.2020.105539

Hviding, E. (1996). Guardians of Marovo lagoon: Practice, place, and politics in maritime Melanesia (Vol. 14). University of Hawai'i Press.

Jentoft, S., Chuenpagdee, R., Barragán-Paladines, M. J., \& Franz, N. (Eds). (2017). The small-scale fisheries guidelines: Global implementation. MARE Series, Vol. 14. Springer. 
Kearney, R. (2013). Australia's out-dated concern over fishing threatens wise marine conservation and ecologically sustainable seafood supply. Open Journal of Marine Science, 3(2), 55-61. https://doi.org/10.4236/ojms.2013.32006

King, T. J. (2018, October 19). Project regard. Youtube video. Retrieved February 5, 2021, from https://www.youtube.com/watch?v=e-QQqx3qGck

King, T. J., \& O’Meara, D. (2019). 'The people have spoken': How cultural narratives politically trumped the best available science (BAS) in managing the port Phillip Bay fishery in Australia. Maritime Studies, 18(1), 17-29. https:// doi.org/10.1007/s40152-018-0097-5

King, T. J., Abernethy, K., Brumby, S., Hatherell, T., Kilpatrick, S., Munksgaard, K., \& Turner, R. (2019). Sustainable fishing families: Developing industry buman capital through health, wellbeing, safety and resilience. Research Project. FRDC 2016-400. Canberra: Fisheries Research and Development Corporation, Deakin University, Western District Health Service, University of Tasmania, and University of Exeter.

Koch, N., \& Perreault, T. (2019). Resource nationalism. Progress in Human Geography, 43(4), 611-631. https://doi.org/10.1177/0309132518781497

Kooiman, J., Jentoft, S., Bavinck, M., \& Pullin, R. (Eds.). (2005). Fish for life: Interactive governance for fisheries. Amsterdam University Press.

Lalancette, A. (2017). Creeping in? Neoliberalism, indigenous realities and tropical rock lobster (kaiar) management in Torres Strait, Australia. Marine Policy, 80, 47-59. https://doi.org/10.1016/j.marpol.2016.02.020

Lau, J. D., Cinner, J. E., Fabinyi, M., Gurney, G. G., \& Hicks, C. C. (2020). Access to marine ecosystem services: Examining entanglement and legitimacy in customary institutions. World Development, 126, 104730. https://doi. org/10.1016/j.worlddev.2019.104730

Levine, M., Thomas, J. B., Sanders, S., Berger, M. F., Gagern, A., \& Michelin, M. (2020). 2020 global landscape review of fishery improvement projects. CEA Consulting. Retrieved February 5, 2021, from https://oursharedseas.com/ oss_downloads/2020-global-landscape-review-of-fishery-improvementprojects/

Li, T. M. (2007). The will to improve: Governmentality, development, and the practice of politics. Duke University Press.

Mansfield, B. (2004). Neoliberalism in the oceans: 'Rationalization', property rights, and the commons question. Geoforum, 35(3), 313-326. https://doi. org/10.1016/j.geoforum.2003.05.002

Mansfield, B. (2007). Privatization: Property and the remaking of nature-society relations introduction to the special issue. Antipode, 39(3), 393-405. https:// doi.org/10.1111/j.1467-8330.2007.00532.x

Matsuda, Y. (1987). Postwar development and expansion of Japan's tuna fishery. In D. Doulman (Ed.), Tuna issues and perspectives in the Pacific Islands region (pp. 71-91). East-West Center. 
McCay, B. J. (1995). Social and ecological implications of ITQs: An overview. Ocean \& Coastal Management, 28, 3-22.

McClean, N., Barclay, K., Fabinyi, M., Adhuri, D. S., Sulu, R. J., \& Indrabudi, T. (2019a). Assessing tuna fisheries governance for community wellbeing: Case studies from Indonesia and Solomon Islands. University of Technology Sydney. Retrieved February 5, 2021, from https://www.uts.edu.au/about/facultyarts-and-social-sciences/research/fass-research-projects/assessinggovernance-tuna

McClean, N., Voyer, M., Davila, F., Barclay, K., Cunningham, R., \& Schnierer, S. (2019b). Analytical report on historical factors and barriers, thematic analysis, typology of stakeholders, and social network analysis. Report Prepared for the Queensland Government, Department of Agriculture and Fisheries. Retrieved January 1, 2021 from https://www.publications.qld.gov.au/dataset/queens land-sustainable-fisheries-strategy/resource/l fb $9427 \mathrm{f}-\mathrm{ecae}-4113$ a9c3-66ee 58 fa2696

McCormack, F. (2013). Commodities and gifts in New Zealand and Hawaiian fisheries. In F. McCormack \& K. Barclay (Eds.), Engaging with capitalism: Case studies from Oceania (pp. 53-81). Emerald Group Publishing Limited. https://doi.org/10.1108/S0190-1281(2013)0000033005

McCormack, F. (2017a). Private oceans: The enclosure and marketisation of the seas. Pluto Press and University of Chicago Press.

McCormack, F. (2017b). Sustainability in New Zealand's quota management system: A convenient story. Marine Policy, 80,35-46. https://doi.org/10.1016/j. marpol.2016.06.022

McLeod, E., Szuster, B., \& Salm, R. (2009). Sasi and marine conservation in Raja Ampat, Indonesia. Coastal Management, 37(6), 656-676. https://doi. org/10.1080/08920750903244143

Minnegal, M., \& Dwyer, P. D. (2008). Managing risk, resisting management: Stability and diversity in a southern Australian fishing fleet. Human Organization, 67(1), 97-108. https://doi.org/10.17730/humo.67.1.x38g60 $\mathrm{k} 463 \mathrm{p} 26855$

Morgan, G. R., \& Staples, D. J. (2006). Tuna longlining, poling and purse seining. In G. R. Morgan \& D. J. Staples (Eds.), The history of industrial marine fisheries in Southeast Asia. UN FAO Regional Office for Asia and the Pacific. Retrieved January 1, 2021, from http://www.fao.org/3/AG122E00. htm\#Contents

Muawanah, U., Yusuf, G., Adrianto, L., Kalther, J., Pomeroy, R., Abdullah, H., \& Ruchimat, T. (2018). Review of national laws and regulation in Indonesia in relation to an ecosystem approach to fisheries management. Marine Policy, 91, 150-160. https://doi.org/10.1016/j.marpol.2018.01.027

Nurasa, T., Naamin, N., \& Basuki, R. (1993). The role of Panglima Laot'sea commander' system in coastal fisheries management in Aceh, Indonesia. TwentySecond IPFC Fisheries Symposium, Darwin, Australia. 
Organisation for Economic Co-operation and Development. (n.d.). Country note on fisheries management systems-Australia. OECD. Retrieved February 5, 2021, from https://www.oecd.org/australia/34427707.pdf

Ostrom, E. (1990). Governing the commons: The evolution of institutions for collective action. Cambridge University Press.

Patterson, H., Woodhams, J., Larcombe, J., \& Curtotti, R. (2020). Chapter 1 overview. In H. Patterson, J. Larcombe, J. Woodhams, \& R. Curtotti (Eds), Fishery status reports 2020 (pp. 1-31). ABARES. Retrieved February 5, 2021, from https://www.agriculture.gov.au/abares/research-topics/fisheries/ fishery-status/overview

Pikitch, E. K., Santora, C., Babcock, E. A., Bakun, A., Bonfil, R., Conover, D. O., Sainsbury, K. J., et al. (2004). Ecosystem-based fishery management. Science, 305(5682), 346-347. https://doi.org/10.1126/science.1098222

Pinkerton, E. (2017). Hegemony and resistance: Disturbing patterns and hopeful signs in the impact of neoliberal policies on small-scale fisheries around the world. Marine Policy, 80(2016), 1-9. https://doi.org/10.1016/j.marpol. 2016.11 .012

Pinkerton, E., \& Edwards, D. N. (2009). The elephant in the room: The hidden costs of leasing individual transferable fishing quotas. Marine Policy, 33(4), 707-713. https://doi.org/10.1016/j.marpol.2009.02.004

Pomeroy, R. S., \& Berkes, F. (1997). Two to tango: The role of government in fisheries co-management. Marine Policy, 21(5), 465-480. https://doi. org/10.1016/S0308-597X(97)00017-1

Quimby, B., \& Levine, A. (2018). Participation, power, and equity: Examining three key social dimensions of fisheries comanagement. Sustainability, 10(9), 3324. https://doi.org/10.3390/sul0093324

Ratner, B. D., Oh, E. J. V., \& Pomeroy, R. S. (2012). Navigating change: Secondgeneration challenges of small-scale fisheries co-management in the Philippines and Vietnam. Journal of Environmental Management, 107, 131-139. https:// doi.org/10.1016/j.jenvman.2012.04.014

Ruddle, K., \& Satria, A. (Eds.). (2010). Managing coastal and inland waters: Preexisting aquatic management systems in Southeast Asia. Springer.

Satria, A., \& Adhuri, D. S. (2010). Pre-existing fisheries management systems in Indonesia, focusing on Lombok and Maluku. In K. Ruddle \& A. Satria (Eds.), Managing coastal and inland waters: Pre-existing aquatic management systems in Southeast Asia (pp. 31-55). Springer.

Schnierer, S., \& Egan, H. (2015). Indigenous cultural fishing and fisheries governance. Research Project. FRDC 2012/216. Fisheries Research and Development Corporation.

Schurman, R. A. (1998). Tuna dreams: Resource nationalism and the Pacific Islands' tuna industry. Development and Change, 29(1), 107-136. https://doi. org/10.1111/1467-7660.00072 
Segi, S. (2014). Protecting or pilfering? Neoliberal conservationist marine protected areas in the experience of coastal Granada, the Philippines. Human Ecology, 42(4), 565-575. https://doi.org/10.1007/s10745-014-9669-1

Shaw, S., Johnson, H., \& Dressler, W. (2011). Identifying, communicating and integrating social considerations into future management concerns in inshore commercial fisheries in coastal Queensland. Research Project. FRDC 2008/073. Canberra and Queensland: Fisheries Research and Development Corporation, University of Queensland, and Queensland Seafood Industry Association.

Stacey, N. E., Karam, J., Meekan, M. G., Pickering, S., \& Ninef, J. (2012). Prospects for whale shark conservation in eastern Indonesia through Bajo traditional ecological knowledge and community-based monitoring. Conservation and Society, 10(1), 63-75. https://doi.org/10.4103/0972-4923.92197

Steenbergen, D. J. (2016). Strategic customary village leadership in the context of marine conservation and development in Southeast Maluku, Indonesia. Human Ecology, 44(3), 311-327. https://doi.org/10.1007/s10745-016-9829-6

Stevens, R., Cartwright, I., \& Neville, P. (2012). Independent review of NSW commercial fisheries policy, management and administration. Department of Primary Industries. Retrieved February 5, 2021, from https://www.dpi.nsw. gov.au/__data/assets/pdf_file/0004/631633/Independent-Comm-FishReview-Report-Mar2012.pdf

Sukarsih, Y., Zulbainarni, N., \& Jahroh, S. (2019). The impact of the moratorium and transhipment policies on the tuna fisheries business in Bitung Indonesia. International Journal of Scientific Technology and Research, 8(4), 329-332.

Sunderlin, W. D., \& Gorospe, M. L. G. (1997). Fishers' organizations and modes of co-management: The case of San Miguel Bay, Philippines. Human Organization, 56(3), 333-343. https://doi.org/10.17730/humo.56.3.457 6w844451k342t

Sunoko, R., \& Huang, H.-W. (2014). Indonesia tuna fisheries development and future strategy. Marine Policy, 43, 174-183. https://doi.org/10.1016/j.marpol. 2013.05 .011

Sutton, M. (2020). South Australian reforms to put two-thirds of local commercial fishers out of business, stakeholders say. Retrieved December 2, 2020, from https://www.abc.net.au/news/2020-11-10/south-australian-scalefishfishery-reforms-impact-on-fishers/12861520

Thorburn, C. C. (2000). Changing customary marine resource management practice and institutions: The case of Sasi Lola in the Kei Islands, Indonesia. World Development, 28(8), 1461-1479. https://doi.org/10.1016/S0305-750X (00)00039-5

Voyer, M., Barclay, K., Mcllgorm, A., \& Mazur, N. (2016). Social and economic evaluation of NSW coastal professional wild-catch fisheries. Research Project. FRDC 2014/301. University of Technology Sydney.

Voyer, M., Barclay, K., McIlgorm, A., \& Mazur, N. (2017). Connections or conflict? A social and economic analysis of the interconnections between the pro- 
fessional fishing industry, recreational fishing and marine tourism in coastal communities in NSW, Australia. Marine Policy, 76, 114-121. https://doi. org/10.1016/j.marpol.2016.11.029

Voyer, M., Quirk, G., McIlgorm, A., \& Azmi, K. (2018). Shades of blue: What do competing interpretations of the blue economy mean for oceans governance? Journal of Environmental Policy \& Planning, 20(5), 595-616. https://doi. org/10.1080/1523908X.2018.1473153

Wallace-Carter, E. (1987). For they were fishers: The history of the fishing industry in South Australia. Amphitrite.

Wilkinson, J. (1997). Commercial fishing in NSW origins and development to the 1990s. Briefing Paper no. 15/1997. NSW parliamentary library research service. Retrieved February 5, 2021, from https://www.parliament.nsw.gov.au/ researchpapers/Pages/commercial-fishing-in-nsw-origins-anddevelopmen.aspx

Wilson, C., \& Linkie, M. (2012). The Panglima Laot of Aceh: A case study in large-scale community-based marine management after the 2004 Indian Ocean tsunami. Oryx, 46(4), 495-500. https://doi.org/10.1017/S00306053 12000191

World Bank. (2015). Indonesia systematic country diagnostic: Connecting the bottom 40 percent to the prosperity generation. Report no. 94066-ID. World Bank.

Zerner, C. (1994). Through a green lens: The construction of customary environmental law and community in Indonesia's Maluku Islands. Law and Society Review, 28(5), 1079-1122. https://doi.org/10.2307/3054024

Open Access This chapter is licensed under the terms of the Creative Commons Attribution 4.0 International License (http://creativecommons.org/licenses/ by $/ 4.0 /$ ), which permits use, sharing, adaptation, distribution and reproduction in any medium or format, as long as you give appropriate credit to the original author(s) and the source, provide a link to the Creative Commons licence and indicate if changes were made.

The images or other third party material in this chapter are included in the chapter's Creative Commons licence, unless indicated otherwise in a credit line to the material. If material is not included in the chapter's Creative Commons licence and your intended use is not permitted by statutory regulation or exceeds the permitted use, you will need to obtain permission directly from the copyright holder.

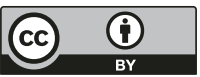

